\title{
On showy dwarfs and sober giants: body size as a constraint for the evolution of bird plumage colouration
}

\author{
Ismael GALVÁN ${ }^{1}$, Juan J. NeGRO ${ }^{2}$, Airam RODRÍGUEZ ${ }^{2}$ \& Luis M. CARRASCAL ${ }^{3}$ \\ ${ }^{1}$ Laboratory of Ecology, Systematics and Evolution, CNRS UMR 8079, University of Paris-Sud 11, Bâtiment 362, Orsay \\ Cedex, FRANCE, e-mail: ism.galvan@gmail.com \\ ${ }^{2}$ Department of Evolutionary Ecology, Doñana Biological Station (Estación Biológica de Doñana, CSIC), Seville, SPAIN \\ ${ }^{3}$ Department of Biogeography and Global Change, National Museum of Natural Sciences (Museo Nacional de Ciencas \\ Naturales, CSIC), Madrid, SPAIN
}

Galván I., Negro J. J., Rodríguez A., Carrascal L. M. 2013. On showy dwarfs and sober giants: body size as a constraint for the evolution of bird plumage colouration. Acta Ornithol. 48: 65-80. DOI 10.3161/000164513X670007

\begin{abstract}
The evolution of bird plumage colouration may be explained by a wide range of selective pressures, including both defensive and advertising needs. However, the relationship between plumage colouration and body size has never been investigated in detail. Here we hypothesize that body size represents a constraint for the evolution of plumage colour heterogeneity because the relative number of body feathers was suggested to increase as body size decreases, and in the case of carotenoid-based colourations because the concentrations of circulating carotenoids decrease with increasing body size. Here we test these predictions on a dataset comprising measurements of male plumage colour heterogeneity using a model of avian visual perception in 111 species from 55 families of birds. A test of the correlation between number of feathers and body size in 92 species of birds showed a positive, instead of negative as previously suggested, association between these variables. As predicted, there was a negative relationship between plumage colour heterogeneity (measured as colour span, a measure of the contrast among colour patches) and body size after controlling for the effects of phylogeny, sexual dichromatism, colour vision type and habitat, and we suggest that the negative allometry shown by carotenoid levels may be the mechanism responsible for this negative relationship. Plumage colour heterogeneity was lower in species inhabiting open environments than in more vegetated habitats. Our results offer a general explanation for interspecific variation in bird colour heterogeneity through an association with body size.
\end{abstract}

Key words: allometry, carotenoids, comparative method, developmental constraints, plumage colour

\section{INTRODUCTION}

Bird plumage colouration is one of the most diverse phenotypic patterns that can be found in nature, and as such it has played an important role in the establishment and development of sexual selection and speciation theories (Darwin 1871, Owens et al. 1999, Hill \& McGraw 2006). Attempts to explain this diversity in colours have been made since the beginning of studies on evolution and adaptation (Darwin 1871, Cott 1940), and currently there is a large number of recognized causes of variation in avian colour patterns, mainly from an intraspecific perspective (e.g., Dale 2006). Interspecific variation in plumage colour is likely to be affected by a variety of factors, such as variation in plumage brightness or hue, sexual dichromatism or delayed plumage maturation (see Owens 2006 for a review), similarity in natural history or ecological attributes (Losos 2008), or niche conservatism related to particular taxonomic groups (e.g. Bretagnolle 1993, Badyaev 1997a,b, Gómez \& Théry 2004). Nevertheless, an important and basic question remains untreated: are there any general rules to explain the entire diversity in plumage colouration?

Using plumage brightness and hue, McNaught \& Owens (2002) found that interspecific variation in plumage colour among six avian families responds to natural selection pressures acting on the signaling capacity of species. Thus, species living in closed habitats tend to present plumage mainly reflecting long-wavelength light (i.e. high- 
er hue values) in order to increase chromatic contrast against surrounding vegetation. Conversely, species living in open habitats have brighter plumage more apt to signal over long distances (McNaught \& Owens 2002). Gómez \& Théry (2004) also concluded that ambient light is the best predictor of interspecific variation in plumage colour in 22 families of tropical birds. Comparing canopy- with ground-living tropical birds, they concluded that the former group of species has a larger variety of hues as a consequence of the broader spectrum of wavelengths to which they are exposed. Apart from these general patterns, other ecological pressures better explain interspecific variation in plumage colour in certain taxonomic groups, such as risk of hybridization with closely related species (Sætre et al. 1997), altitudinal distribution (Badyaev 1997a,b), display complexity (Galván 2008) or foraging and hunting mode (Preston 1980, Bretagnolle 1993). Therefore, the basic question formulated in the previous paragraph is probably better addressed through the study of why some species have a large colour heterogeneity while others are uniformly coloured, independently of the intensity of each colour they present.

All the aforementioned studies deal with ecological factors that affect across-species variation in plumage colouration, although the high diversity of selective pressures leading to the evolution of colour patterns may prevent us from finding general rules to explain colour variation. There is ample evidence supporting the importance of ambient light as an agent affecting plumage colour heterogeneity (Owens 2006), but this cannot be applied to certain taxonomic groups where other evolutionary forces are acting (Preston 1980, Bretagnolle 1993, Badyaev 1997a,b, Sætre et al. 1997, Galván 2008). In order to have a more general explanation for the observed heterogeneity in plumage colouration within individuals, more basic questions are needed. The importance of developmental constraints in explaining interspecific variation in plumage colour has rarely been recognized, and only for certain taxonomic groups (Price \& Pavelka 1996). In fact, until recently it had not been properly demonstrated that the dynamic of feather growth has a deterministic role in the expression of plumage colouration at the intraspecific level (Badyaev \& Landeen 2007).

Body mass accounts for a large proportion of interspecific variation in several aspects related to life-history (Peters 1983), and may pose a possible constraint for the development of plumage colouration in birds. This idea is based on the finding of Tella et al. (2004), who reported that carotenoid concentration in plasma increases as species body size decreases, since smaller bird species have higher food intake rates per unit of body mass as required by their high metabolic rates, and thus the amount of these pigments included in the diet. Therefore, this limitation in the levels of circulating carotenoids may impose a constraint to the evolution of bird plumage colouration generated by carotenoids. The carotenoids deposited in feathers are either directly ingested with the diet, or converted in the body from precursor carotenoids (e.g., del Val et al. 2009). Thus, at an interspecific level, we assume that higher plasma carotenoids are positively associated with the number of colour patches in feathers, and this relationship is the same for all birds. We therefore predicted a negative correlation between body size and number of different colours generated by carotenoids among species of birds, considering the latter variable as the number of different hues (i.e., yellow, red, etc) shown by a given species. A negative correlation between the number of plumage colours and body mass at the interspecific level could be also predicted considering that the number of contour body feathers per unit of body mass has been suggested to decrease as the species body size increases (Hutt \& Ball 1938, but see Campbell \& Lack 1985). The probability of generating patches of different colours might increase with the number of feathers on which those colours are shown. This would be probably true even if relative patch size would decrease with body size, as many small patches are not perceived as well as larger patches (Galván 2008). Therefore, a negative relationship between body size and plumage colour heterogeneity among species of birds is predicted again.

Surprisingly, the relationship between body size and plumage colour heterogeneity has never been reported. If anything, previous papers tangential to this topic are those by Badyaev (1997a), who reported no effect of body size on overall plumage brightness of cardueline finches, Bretagnolle (1993), who reported that body mass was positively correlated with the proportion of white in albatrosses and Negro et al. (2006), who reported an association between large size, dark plumage colour and facial flushing colouration. Furthermore, opposing natural and sexual selection pressures are often expressed by different colour components, the latter mainly favouring 
brighter colours (Hill 2006). Natural selection imposes limits on the development of traits under sexual selection regimes (e.g., Evans 2004). Thus, birds with large numbers of feathers might be less constrained to generate ornamented feathers and birds with fewer feathers might be mainly exposed to natural selection pressures, which promote dark colours (melanin-based black, brown and chestnut; Hill 2006), hence limiting the possibilities to develop different colours.

The aim of our study is to analyse the relationship between body size and within-individual plumage colour heterogeneity in birds. With this aim, we used the dataset generated by Stoddard \& Prum (2011) comprising measurements of male plumage colour heterogeneity using a model of avian visual perception in 111 species from 55 families of birds. Given the importance of ambient light in determining variation in plumage colour among many groups of birds (Owens 2006), the universal, inverse association between ambient light and habitat structure - volume of vegetation, and the close relationship among body mass, habitat preferences and spatial niche (Polo \& Carrascal 1999), the influence of habitat preferences are controlled for when searching for a relationship between plumage colour heterogeneity and body size. Sexual dichromatism in plumage is also controlled for, as males of dichromatic species present a greater potential of exhibiting a more diverse plumage colouration than males of monochromatic species. This descriptive approach to interspecific variation is important because it focuses on how the tendency of species to retain ancestral colouration characteristics may limit the expression of ecological pressures such as visual communication under different ambient light levels and sexual selection on plumage colouration. Finally, we also investigate whether the number of contour body feathers is associated to body size using counts of body feathers.

\section{MATERIALS AND METHODS}

\section{Plumage colour data}

Stoddard \& Prum (2011) measured reflectance spectra of 965 plumage patches on male specimens of 111 species from 55 families of birds using an S2000 Ocean Optics spectrophotometer (Dunedin, Florida). These authors took reflectance measurements from six standard plumage patches per specimen, and up to seven additional patches were also considered in some species that presented additional colours as perceived by the human eye. These measurements comprised a diverse set of colours generated by virtually all known colouration mechanisms: melanins (eu- or pheomelanin), carotenoids (red, orange, yellow, or purple), porphyrins (turacin or turacoverdin), psittacofulvins, structural (spongy barb rami or barbule melanin arrays), white (normal unpigmented or spongy barb white), or a combination of structural and pigmentary mechanisms (Stoddard \& Prum 2011). Reflectance measurements were analyzed using the Goldsmith's (1990) tetrahedral colour space, which considers reflectance information along with the sensitivity of each of the four retinal cone cells of birds to put them in a tetrahedron whose center is the achromatic point and whose geometry allows to define each colour point by a vector with spherical coordinates composed of angles (which define the colour hue) and distances (which define the colour chroma) generated between the colour points and the achromatic origin (see Stoddard \& Prum 2008, 2011 for further details on colour modelling). This allowed Stoddard \& Prum (2011) to calculate the volume of the colour space of the species, as well as measures of colour span (the average of the Euclidean distances between each pair of colors) and hue disparity (magnitude of the angle between two colour vectors). Plumage colour volume is a measure of colour diversity, colour span a measure of the overall contrast among colour patches, and hue disparity a measure of overall hue contrast independent of chroma (Stoddard \& Prum 2008). Thus, a plumage with a few highly contrasting colours may have a large value of colour span and a low value of colour volume, while a plumage with many poorly differentiated colours may have a low value of colour span and a high value of colour volume (Stoddard \& Prum 2008). However, as these three measures can be interpreted as indexes of plumage colour heterogeneity within individuals, we use colour volume, colour span and hue disparity as provided in Supplementary Table 1 by Stoddard \& Prum (2011) in our analyses of the relationship between colour heterogeneity and body size. Since Stoddard \& Prum's (2011) measurements were obtained objectively using a spectrophotometer and an avian visual model, they likely reveal plumage colour heterogeneity as must be perceived by birds. Information on plumage colour diversity variables for the 111 species of birds is summarized here in Appendix 1 . 


\section{Sexual dichromatism}

Information on sexual dichromatism in plumage was obtained by examining illustrations and text descriptions of birds in del Hoyo et al. (1992-2002, 2003-2010). A species was considered to be sexually dichromatic (score 1 ) when both sexes exhibited a conspicuous and clearly distinguishable difference in plumage colouration. Otherwise the species were categorised as monochromatic (score 0 ). Seddon et al. (2010) have recently shown that human visual assessment of sexual dichromatism is positively correlated with the avian perception of the trait. Information on sexual dichromatism is provided in Appendix 1.

Body size and coarse-grained habitat information We took body mass as an estimation of the body size of the species. Body mass data of males (or, when information for males was not available, the mean mass of males and females or the average of body mass range) were obtained from Dunning (1993). When information for certain species was not available from the latter, this was taken from del Hoyo et al. (1992-2002, 2003-2010), from Day et al. (2005) for the Great Bowerbird Chlamydera nuchalis and from BirdLife International (2011) for the Flame-breasted Fruit Dove Ptilinopus marchei. For the Barn Owl Tyto alba, we used information on the North American subspecies (T. a. pratincola). Since Stoddard \& Prum (2011) treated the Greater Flamingo Phoenicopterus roseus and the American Flamingo Phoenicopterus ruber as distinct species, but the former is considered a subspecies of the latter by del Hoyo et al. (1992-2002), we assigned the same body mass to both species. Information on the body mass of the species is provided in Appendix 1.

Structural complexity and vegetation volume of the preferred habitat of each species (hereafter, coarse-grained habitat preference) was scored following an increasing multinomial order variable: -1 for habitats with very sparse vegetation cover, mainly pasturelands and shrublands with sparse vegetation cover made up of bushes lower than 1 $\mathrm{m}$ (hereafter 'open country' habitats); 0 for open woodlands with scattered trees, such as parklands, narrow riparian woods, hedgerows, savannah like habitats; and finally +1 for dense forests with tall trees. This classification is meaningful in understanding coarse-grained patterns related to ecological implications of habitat preferences. The information about habitat structure was obtained from del Hoyo et al. (1992-2002, 2003-2010), and is shown in Appendix 1.

\section{Relationship between body size and number of feathers}

Hutt \& Ball (1938), on the basis of information on number of contour feathers previously reported by Wetmore (1936), concluded that the number of contour feathers decreases with body size in birds. However, these authors regressed the number of feathers divided by body mass against body mass, invalidating the analysis because the explanatory variable was not independent from the response variable, as it included the predictor in the denominator. Therefore, we re-analysed the data provided by Wetmore (1936), adding some information on number of contour feathers reported by Campbell \& Lack (1985). For consistency, when data on a given species was available in both Wetmore's (1936) and Campbell \& Lack's (1985) datasets, we only used the information from the former. When information on more than one specimen was available for a given species, we used the average number of all specimens. Also for consistency with the previous analyses of Wetmore (1936) and Campbell \& Lack (1985), the body mass of the species was taken from either these sources or, when not available, from Dunning (1993) as in the previous analysis of plumage colour (see above). In total, we compiled information on number of feathers and body mass for 92 species of birds (Appendix 2). We did not control for phylogeny in this analysis because we were only interested in determining whether the negative allometry in the number of feathers suggested by Hutt \& Ball (1938) was true, and the tendency that we found was indeed opposite to that suggestion (see Results).

\section{Data analyses}

Bird species are evolutionarily related through phylogeny, and therefore, they should not be treated as independent sample units (Felsenstein 1985, Harvey \& Purvis 1991). Therefore, the effect of common ancestry among taxa can lead to an overestimation of degrees of freedom if phylogenetic relationships are not taken into account (see Garland et al. 2005 for a recent review). We used phylogenetic generalized least squares (PGLS) models (Martins \& Hansen 1997) to control for phylogenetic effects in the analyses of the relationship between colour variables and body size and habitat preferences. PGLS is an extension of Grafen's (1989) phylogenetic regression, where phylogenetic relationships among species are used to calculate the variances and covariances of the traits. PGLS models thus establish the depend- 
ence structure among observations through a variance-covariance matrix (Martins \& Hansen 1997). We ran PGLS models as implemented in $R$ 2.12.2 (R Development Core Team 2011) with an unpublished function by R. Freckleton (University of Sheffield) (pglm3.4.r, available on request), and using the appropriate libraries („ape”, "MASS” and „mvtnorm”). This function performs PGLS as developed by Martins \& Hansen (1997) and calculates the measure of phylogenetic correlation $(\lambda)$ established by Pagel (1999). $\lambda$ is a likelihood ratio test that assumes a constant-variance random effects model of evolution (i.e., Brownian model) and adjusts the analyses for the degree of dependence among traits, considering that this degree can vary between a complete independence of data on phylogeny $(\lambda=0$; which would result in a star phylogeny) and a complete dependence of data on phylogeny $(\lambda=1$; which would mean that traits covary in direct proportion to their shared evolutionary history)(Pagel 1999). We used Freckleton et al.'s (2002) procedure for PGLS models, which finds the covariance between pairs of traits that is optimal under a common random effects Brownian process (Freckleton et al. 2002). Therefore, we used Freckleton's function for PGLS to calculate the maximum likelihood (optimal) value of $\lambda$ in our dataset given the phylogenetic hypothesis (see below) and performed the PGLS models described above adjusting for phylogenetic effects through $\lambda$.

The phylogenetic relationships (Appendix 3) were mainly taken from the recent study of Hackett et al. (2008). These authors constructed an avian phylogeny by using nuclear DNA sequence data from all but three nonpasserine families. As information from passerine families in that phylogeny is however incomplete, we used the study of Barker et al. (2004), also based on nuclear DNA sequence data, to determine phylogenetic relationships among passerine families. In addition, we used other studies to complete information on relationships between particular families. Thus, we used the supertree constructed by Jønsson \& Fjeldså (2006) from 97 studies based on different molecular datasets (mitochondrial genes, nuclear genes, both nuclear and mitochondrial genes or mitochondrial and morphological data) to determine the position of the families Coerebidae and Estrildidae. The study of Barker et al. (2001), based on nucleotide sequence variation, was used to determine the position of the families Cardinalidae, Thraupidae and Icteridae. Information on phylogenetic relationships among nonpasserine families was completed with the study of Ericson et al. (2006) from genomic DNA to determine the position of Ramphastidae. Relationships between species within families were taken from the species-level supertree constructed by Davis (2008), with additional information from McGuire et al. (2007) to establish the relationships between hummingbird species, and from Wright et al. (2008) to establish the relationships between some parrot species. Ptilinopus magnificus was considered as the sister species of both $P$. marchei and $P$. jambu because different studies have found that the former is the sister species to other Ptilinopus species (Davis 2008, Gibb \& Penny 2010). As not all these phylogenies were calibrated (i.e., estimates of ages for nodes were not available), and different methods were used to build the phylogenies, we set all branch lengths equal to unity in our compiled phylogeny, thus assuming a speciational model of evolution.

In the PGLS models, the colour response variables (colour volume, colour span and hue disparity) were regressed on body mass ( $\log _{10}$-transformed), coarse grained habitat preferences and sexual dichromatism. For habitat preferences we used a linear contrast table, ordering the three levels of this factor according to the following sequence: treeless 'open country' (factor score -1), open woodlands $(0)$, dense forest $(+1)$. We also added the type of colour vision of the species (i.e., the fourth cone uses either ultraviolet-sensitive (UVS), code 1 , or violet-sensitive (VS), code 0 , opsin pigments) as an additional covariate to the models, because Stoddard \& Prum (2011) have found that the avian plumage colour gamut is higher for the species with UVS system, and this may thus represent a confounding variable. Information on the type of colour vision was taken from the Supplementary Table 1 provided by Stoddard \& Prum (2011; see Appendix 1).

\section{RESULTS}

\section{Relationship between body size and plumage colour heterogeneity}

The global model (i.e. using the full set of predictor variables) for colour span showed an optimal value for $\lambda$ of 0.169 . At this value, the model was significant $\left(\mathrm{F}_{4,106}=5.14, \mathrm{p}=0.001\right)$ and explained $16.2 \%$ of variance in colour span among species. As predicted, body mass had a negative and significant effect on colour span $(b=-0.038, t=-3.37$, $\mathrm{p}=0.001)$, indicating that the colour span of 
plumage decreased with the body size of the species. The linear (ordered) influence of the structural complexity of preferred habitats was positive and significant $(\mathrm{b}=0.027, \mathrm{t}=2.17$, $\mathrm{p}=0.032$ ): it increased from 'open country' treeless habitats to more vegetated environments. By contrast, non-significant effects were found for sexual dichromatism $(\mathrm{b}=-0.009, \mathrm{t}=-0.57$, $\mathrm{p}=0.572)$ and type of colour vision $(\mathrm{b}=0.012$, $\mathrm{t}=0.54, \mathrm{p}=0.590)$. When these non-significant terms were removed from the model, the optimal value of $\lambda$ was 0.238 , value at which the model was highly significant $\left(\mathrm{F}_{2,108}=9.01, \mathrm{p}<0.001\right)$ and explained $14.3 \%$ of variance in colour span. The effect of body mass did not change (body mass: $\mathrm{b}=-0.036, \mathrm{t}=-3.23, \mathrm{p}=0.002$; Fig. 1 ), and the effect of habitat preference changed to marginally non-significant $(b=0.023, t=1.96, p=0.052$; Fig. 2).

The model for hue disparity showed that this variable had a stronger phylogenetic signal $(\lambda=0.509)$ than color span. In the maximal model, only the effect of habitat preference was significant $(\mathrm{b}=0.214, \mathrm{t}=2.45, \mathrm{p}=0.016$; body mass: $\mathrm{b}=-0.028, \mathrm{t}=-0.33, \mathrm{p}=0.738$; sexual dichromatism: $\mathrm{b}=-0.131, \mathrm{t}=-1.24, \mathrm{p}=0.217$; colour vision type: $\mathrm{b}=6.45 \times 10^{-3}, \mathrm{t}=0.039, \mathrm{p}=0.968$ ). The reduced model including only the effect of habitat preference was significant $\left(\mathrm{F}_{1,109}=5.54, \mathrm{p}=0.020\right)$ explained $4.8 \%$ of variance in hue disparity, indicating that plumage hue disparity also increased with habitat complexity.

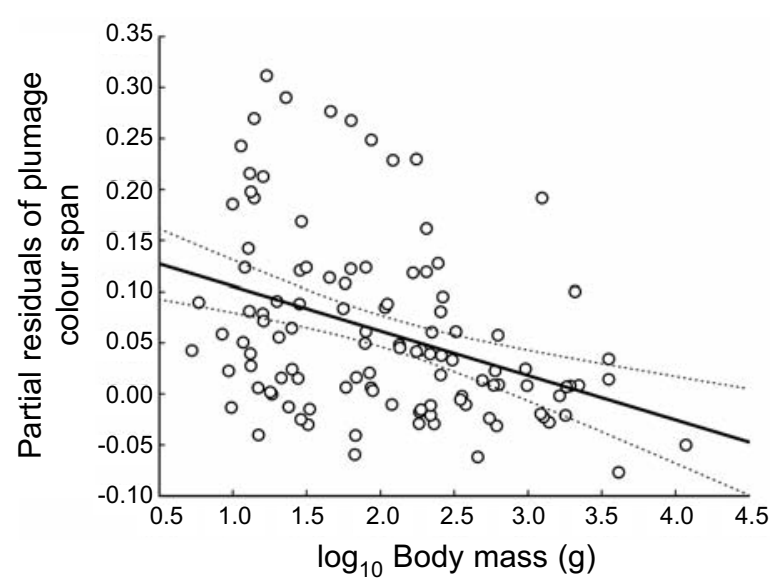

Fig. 1. Relationship between plumage colour span and body mass $\left(\log _{10}\right.$-transformed), after controlling for the effects of habitat preferences and phylogenetic signal. The residual figures of the response variable are shown (i.e., partial effects after applying a PGLS model without body mass). The dotted lines show the $95 \%$ confidence intervals for the regression line. $\mathrm{n}=111$ species.

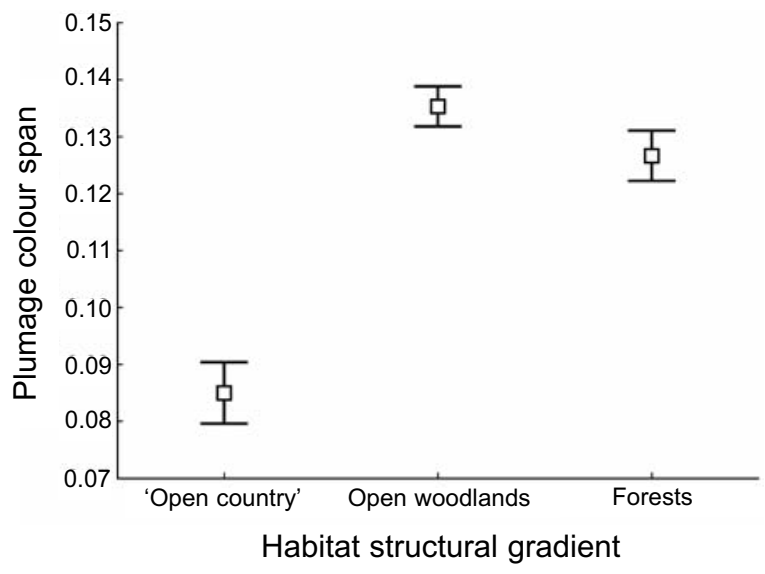

Fig. 2. Adjusted means $( \pm \mathrm{SE}$ ) for plumage colour span of 111 species of birds, according to coarse-grained habitat preferences, after controlling for the covariation with body mass and phylogeny. Sample sizes: open country' habitats -11 species, open woodlands -69 species, dense forests -31 species.

The model for colour volume showed that this variable had a phylogenetic signal $(\lambda=0.182)$ similar to that of colour span and then weaker than hue disparity. The only significant term in the maximal model for this variable was colour vision type $(\mathrm{b}=0.001, \mathrm{t}=2.84, \mathrm{p}=0.005$; body mass: $\mathrm{b}=-10^{-5}, \mathrm{t}=-0.49, \mathrm{p}=0.628$; habitat preference: $\mathrm{b}=2.68 \times 10^{-4}, \mathrm{t}=1.17, \mathrm{p}=0.242$; sexual dichromatism: $\left.\mathrm{b}=3.87 \times 10^{-5}, \mathrm{t}=0.133, \mathrm{p}=0.894\right)$. The reduced model including only the effect of colour vision type was significant $\left(\mathrm{F}_{1,109}=7.15\right.$, $p=0.009)$ and explained $6.1 \%$ of variance in colour volume, indicating that plumage colour volume was greater for species with UVS-colour vision than for species with VS-colour vision.

\section{Relationship between body size and number of feathers}

A Pearson correlation test between $\log _{10}$-number of feathers and $\log _{10}$-body mass showed a positive correlation between these variables $(r=0.86$, $\mathrm{n}=92$ ). This indicates that an association between number of feathers and body mass cannot represent a mechanism that explains the negative relationship between plumage colour heterogeneity and body size found here.

\section{DISCUSSION}

Plumage colour heterogeneity (colour span) decreased as the species size increased after controlling for the effects of habitat, sexual dichromatism, 
colour vision type and phylogeny. Body size thus appears as a potential constraint for the evolution of bird colouration. This constraint has been so far overlooked, but our finding suggests that future studies of plumage colour heterogeneity at the interspecific level should consider body size as a confounding variable.

We only found a significant effect of body size in one of the three different measures of plumage colour heterogeneity provided by Stoddard \& Prum (2011), i.e. colour span. The amount of phylogenetic signal was also different between these measures, because it was relatively low in colour span and colour volume $(\lambda=0.24$ and 0.17 , respectively), but was considerably greater in hue disparity $(\lambda=0.52)$. Therefore, although colour volume, colour span and hue disparity are alternative measures of plumage colour heterogeneity (Stoddard \& Prum 2008), their evolution may respond to different factors. This is likely, as the particular biological significance of these measures differ. Plumage colour volume quantifies the overall diversity of colours within a plumage (i.e., how many different colour patches, independently of how different they are perceived by birds, occur in a plumage), colour span quantifies the contrast among colour patches (i.e., how different are perceived the colour patches within a plumage), and hue disparity is an aspect of the uniformity of the variation in hue among colour patches within a plumage (Stoddard \& Prum 2008). Thus, the effect of body size was only found on the level of contrast among plumage colour patches, which suggests that the evolution of this plumage colour property, but not other properties such as the number of different hues independently of how different they are, is constrained by body size. Future studies should investigate why the three measures of plumage colour heterogeneity also present different phylogenetic inertia. In any case, the difference in the phylogenetic inertia indicates that the number of different hues is more labile than the overall contrast beween colour patches, which should be considered by studies on the evolution of plumage colouration.

Our study thus opens new avenues for research, in which body size may be considered a potential explanatory factor for several ecological patterns related to bird plumage colouration. For example, it could be postulated that one mechanism responsible for the negative association between plumage colour diversity and body size is the predicted negative relationship between species body size and plasma carotenoid levels found by Tella et al. (2004), as carotenoid levels may not only limit the proportion of coloured plumage, but also the possibilities to generate different contrasting colours which is the property that colour span measures. The functional link between circulating carotenoid levels and body size may be due to the fact that smaller species consume higher amounts of food (from which carotenoids must be taken) per unit of body mass than larger species because of their high metabolic rates (Tella et al. 2004). Plumage colours generated by carotenoids represent $13.6 \%$ of the avian plumage colour gamut, and these pigments are present in most colours generated by a combination of different pigments or of pigments and specialized feather structures, which represent $36.2 \%$ of the avian plumage colour gamut (Stoddard \& Prum 2011). Thus, natural selection pressures acting on the carotenoid levels through its association with body size could represent constraints for the development of plumage colour. Although our dataset included some species of parrots (Order Psittaciformes), which are known to not deposit carotenoids in feathers (Stoddard \& Prum 2011), they only represent a small portion of the total of species considered in the analyses (Appendix 1), so the association between plumage colour heterogeneity and body size may still be observed even if the allometry in plasma carotenoid levels is actually a responsible mechanism. Furthermore, other alternative hypotheses may be formulated to explain our results (see below).

An alternative, but not exclusive hypothesis, is that the tendency of smaller birds to exhibit more contrasting colour patches in their plumage is not a consequence of physiological constraints, but an adaptation to their visual communication needs, as the spatial distance for detecting conspecifics (i.e. viewing distance) seems to be positively related to body size (Kiltie 2000). This means that larger species are able to detect conspecifics at longer distances, and thus smaller species may be forced to develop more conspicuous colourations to be used in intraspecific interactions. This idea is reinforced by the fact that, on average, small-sized species usually inhabit more dense habitats (Polo \& Carrascal 1999) where vegetation constrains visual detection at distance, thus the derived need to be more conspicous. However, visual acuity does not scale with body size like viewing distance (Kiltie 2000), so that longer detection distances are not translated into better resolution. Furthermore, plumage colour patches are not 
only aimed at improving the possibility of being detected, but also contain information not merely related to presence that requires close examination among conspecifics (Dale 2006).

Finally, plumage colour heterogeneity in open habitats tended to be lower than in the rest of habitat types. Since natural selection exerts stronger pressure on open habitats due to higher predation risk (Götmark \& Post 1996, Rodríguez et al. 2001), birds living in those environments should have a limited repertoire of plumage colouration. In fact, ground-nesting birds, which generally correspond to birds living in open habitats, exhibit more cryptic colours than birds nesting on trees or other structures associated to closed habitats (Haskell 1996). Our study suggests that the role of natural selection in limiting the evolution of contrasting plumage colours in open habitats could be generalized to several avian families and thus constitutes an important evolutionary force.

Given that body mass accounts for a large proportion of interspecific variation in several aspects related to life-history (Peters 1983), plumage colour heterogeneity is likely to have coevolved with several life-history characteristics if it is indeed constrained by body size. The importance of plumage colouration in evolutionary studies, exemplified by its role in developing early ideas on evolution and adaptation (Darwin 1871, Cott 1940), makes us predict that the general pattern that we are reporting here will have broad implications for understanding the ecological context in which many evolutionary processes associated with plumage colour, such as sexual selection, social signaling or concealment (Hill \& McGraw 2006), occur.

\section{ACKNOWLEDGEMENTS}

I.G. was supported by a Marie Curie IntraEuropean Fellowship (PIEF-GA-2009-252145) within the 7th European Community Framework Programme, and A.R. from a I3P predoctoral grant from Consejo Superior de Investigaciones Científicas (CSIC). J.J.N. and A.R. were supported by Project CGL2006-07481, funded by the Ministry of Science and Innovation. We thank Anders Pape Møller, Gary Bortolotti and Graeme Ruxton for numerous and constructive comments on previous drafts. Claire Jasinski kindly improved the English of an early draft, and Javier Seoane helped us with some references. Rob Freckleton kindly provided us with his $\mathrm{R}$ function for PGLS analyses.

\section{REFERENCES}

Badyaev A. V. 1997a. Altitudinal variation in sexual dimorphism: a new pattern and alternative hypotheses. Behav. Ecol. 8: 675-690.

Badyaev A. V. 1997b. Covariation between life history and sexually selected traits: an example with cardueline finches. Oikos 80: 128-138.

Badyaev A. V., Landeen E. A. 2007. Developmental evolution of sexual ornamentation: model and a test of feather growth and pigmentation. Int. Comp. Biol. 47: 221-233.

Barker F. K., Barrowclough G. F., Groth J. G. 2001. A phylogenetic hypothesis for passerine birds: taxonomic and biogeographic implications of an analysis of nuclear DNA sequence data. Proc. R. Soc. B 269: 295-308.

Barker F. K., Cibois A., Schikler P., Feinstein J., Cracraft J. 2004. Phylogeny and diversification of the largest avian radiation. Proc. Natl. Acad. Sci. USA 101: 1104011045.

BirdLife International 2011. Species factsheet: Ptilinopus marchei. Downloaded from http://www.birdlife.org on 08/11/2012.

Bretagnolle V. 1993. Adaptive significance of seabird coloration: the case of procellariiforms. Am. Nat. 142: 141-173.

Campbell B., Lack E. 1985. A Dictionary of Birds. T \& AD Poyser, Calton.

Cott H. B. 1940. Adaptive coloration in animals. Methuen \& Co. Ltd, London.

Dale J. 2006. Intraspecific variation in coloration. In: Hill G. E., McGraw K. J. (eds). Bird Coloration. Vol. II: Function and Evolution. Harvard University Press, Cambridge, pp. 36-86.

Darwin C. 1871. The descent of man, and selection in relation to sex. Murray, London.

Davis K. E. 2008. Reweaving the Tapestry: A Supertree of Birds. Ph.D. Thesis, University of Glasgow.

Day L. B., Westcott D. A., Olster D. H. 2005. Evolution of bower complexity and cerebellum size in bowerbirds. Brain Behav. Evol. 66: 62-72.

del Hoyo J., Elliot A., Sargatal J. (eds). 1992-2002. Handbook of the Birds of the World. Vols. 1-7. Lynx Edicions, Barcelona.

del Hoyo J., Elliot A., Christie D. A. (eds). 2003-2010. Handbook of the Birds of the World. Vols. 8-15. Lynx Edicions, Barcelona.

del Val E., Senar J. C., Garrido-Fernández J., Jarén M., Borrís A., Cabrera J., Negro J. J. 2009. The liver but not the skin is the site for conversion of a red carotenoid in a passerine bird. Naturwissenschaften 96: 797-801.

Dunning J. B. 1993. CRC Handbook of Avian Body Masses. CRC Press, Boca Ratón.

Ericson P. G. P., Anderson C. L., Britton T., Elzanowski A., Johansson U. S., Källersjö M., Ohlson J. I., Parsons T. J., Zuccon D., Mayr G. 2006. Diversification of Neoaves: integration of molecular sequence data and fossils. Biol. Lett. 2: 543-547.

Evans M. R. 2004. Limits on the evolution of tail ornamentation in birds. Am. Nat. 163: 341-357.

Felsenstein J. 1985. Phylogenies and the comparative method. Am. Nat. 125: 1-15.

Freckleton R. P., Harvey P. H., Pagel M. 2002. Phylogenetic analysis and comparative data: a test and review of evidence. Am. Nat. 160: 712-726. 
Galván I. 2008. The importance of white on black: unmelanized plumage proportion predicts display complexity in birds. Behav. Ecol. Sociobiol. 63: 303-311.

Garland T. Jr., Bennett A. F., Rezende E. L. 2005. Phylogenetic approaches in comparative physiology. J. Exp. Biol. 208: 3015-3035.

Gibb G. C., Penny D. 2010. Two aspects along the continuum of pigeon evolution: a South-Pacific radiation and the relationship of pigeons within Neoaves. Mol. Phylogen. Evol. 56: 698-706

Goldsmith T. H. 1990. Optimization, constraint, and history in the evolution of eyes. Q. Rev. Biol. 65: 281-322.

Gómez D., Théry M. 2004. Influence of ambient light on the evolution of colour signals: comparative analysis of a Neotropical rainforest bird community. Ecol. Lett. 7: 279-284.

Götmark F., Post P. 1996. Prey selection by sparrowhawks, Accipiter nisus: relative predation risk for breeding passerine birds in relation to their size, ecology and behaviour. Phil. Tran. R. Soc. B 351: 1559-1577.

Grafen A. 1989. The phylogenetic regression. Phil. Trans. R. Soc. Lond. B 326: 119-156.

Hackett S. J., Kimball R. T., Reddy S., Bowie R. C. K., et al. 2008 A phylogenomic study of birds reveals their evolutionary history. Science 320: 1763-1768.

Harvey P. H., Purvis A. 1991. Comparative methods for explaining adaptations. Nature 351: 619-624.

Haskell D. G. 1996. Do bright colors at nests incur a cost due to predation? Evol. Ecol. 10: 285-288.

Hill G. E. 2006. Female mate choice for ornamental coloration. In: Hill G. E., McGraw K. J. (eds). Bird Coloration. Vol. II Function and Evolution. Harvard University Press, Cambridge, pp. 137-200.

Hill G. E., McGraw K. J. 2006. Bird Coloration. Vol. II: Function and Evolution. Harvard University Press, Cambridge.

Hutt F. B., Ball L. 1938. Number of feathers and body size in passerine birds. Auk 55: 651-657.

Jønsson K. A., Fjeldså J. 2006. A phylogenetic supertree of oscine passerine birds (Aves: Passeri). Zool. Scr. 35: 149-186.

Kiltie R. A. 2000. Scaling of visual acuity with body size in mammals and birds. Funct. Ecol. 14: 226-234.

Losos J. B. 2008. Phylogenetic niche conservatism, phylogenetic signal and the relationship between phylogenetic relatedness and ecological similarity among species. Ecol. Lett. 11: 995-1007.

Martins E. P., Hansen T. F. 1997. Phylogenies and the comparative method: a general approach to incorporating phylogenetic information into the analysis of interspecific data. Am. Nat. 149: 646-667.

McGuire J. A., Witt C. C., Altshuler D. L., Remsen J. V. 2007. Phylogenetic systematics and biogeography of hummingbirds: Bayesian and maximum likelihood analyses of partitioned data and selection of an appropriate partitioning strategy. Syst. Biol. 56: 837-856.

McNaught M. K., Owens I. P. F. 2002. Interspecific variation in plumage colour among birds: species recognition or light environment? J. Evol. Biol. 15: 505-514.

Negro J. J., Sarasola J. H., Fariñas F., Zorrilla I. 2006. Function and occurrence of facial flushing in birds. Comp. Biochem. Physiol. A 143: 78-84.

Owens I. P. F. 2006. Ecological explanations for interspecific variability in coloration. In: Hill G. E., McGraw K. J. (eds) Bird Coloration. Vol. II: Function and Evolution. Harvard University Press, Cambridge, pp. 380-416.

Owens I. P. F., Bennett P. M., Harvey P. H. 1999. Species richness among birds: body size, life history, sexual selection or ecology? Proc. R. Soc. B 266: 933-939.
Pagel M. 1999. Inferring the historical patterns of biological evolution. Nature 401: 877-884.

Peters R. H. 1983. The ecological implications of body size. 1st edn. Cambridge University Press, Cambridge.

Polo V., Carrascal L. M. 1999. Shaping the body mass distribution of Passeriformes: habitat use and body mass are evolutionarily and ecologically related. J. Anim. Ecol. 68: 324-337.

Preston C. R. 1980. Differential perch site selection by color morphs of the Red-tailed Hawk (Buteo jamaicensis). Auk 97: 782-789.

Price T., Pavelka M. 1996. Evolution of a colour pattern: history, development, and selection. J. Evol. Biol. 9: 451-470.

$\mathrm{R}$ Development Core Team 2011. R: a language and environment for statistical computing. Vienna.

Rodríguez A., Andrén H., Jansson G. 2001. Habitat-mediated predation risk and decision making of small birds at forest edges. Oikos 95: 383-396.

Sætre G.-P., Moum T., Bureš S., Král M., Adamjan M., Moreno J. 1997. A sexually selected character displacement in flycatchers reinforces premating isolation. Nature 387: 589-592.

Seddon N., Tobias J., Eaton M., Odeen A. 2010. Human vision can provide a valid proxy for avian perception of sexual dichromatism. Auk 127: 283-292.

Stoddard M. C., Prum R. O. 2008. Evolution of avian plumage color in a tetrahedral color space: a phylogenetic analysis of new world buntings. Am. Nat. 171: 755-776.

Stoddard M. C., Prum R. O. 2011. How colorful are birds? Evolution of the avian plumage color gamut. Behav. Ecol. 22: 1042-1052.

Tella J. L., Figuerola J., Negro J. J., Blanco G., Rodríguez-Estrella R., Forero M. G., Blázquez M. C., Green A. J., Hiraldo F. 2004. Ecological, morphological and phylogenetic correlates of interspecific variation in plasma carotenoid concentration in birds. J. Evol. Biol. 17: 156-164.

Théry M. 2006. Effects of light environment on color communication. In: Hill G. E., McGraw K. J. (eds). Bird Coloration. Vol. I: Mechanisms and Measurements. Harvard University Press, Cambridge, pp. 148-173.

Wetmore A. 1936. The number of contour feathers in passeriform and related birds. Auk 53: 159-169.

Wright T. F., Schirtzinger E. E., Matsumoto T., Eberhard J. R., Graves G. R., Sánchez J. J., Capelli S., Müller H., Scharpegge J., Chambers G. K., Fleischer R. C. 2008. A multilocus molecular phylogeny of the parrots (Psittaciformes): support for a Gondwanan origin during the Cretaceous. Mol. Biol. Evol. 25: 2141-2156.

\section{STRESZCZENIE}

[Wielkość ciała jako czynnik ograniczający w ewolucji ubarwienia upierzenia ptaków]

Ewolucja ubarwienia ptasiego upierzenia jest wiązana $\mathrm{z}$ wieloma czynnikami selekcyjnymi, $\mathrm{w}$ tym $\mathrm{z}$ z ochroną przez drapieżnikami oraz możliwością komunikowania różnych informacji. Jednak potencjalny związek pomiędzy ubarwieniem upierzenia i wielkością ciała nie był do tej pory rozpatrywany. Autorzy stawiają hipotezę, że wielkość ciała stanowi czynnik ograniczający $\mathrm{w}$ ewolucji ubarwienia upierzenia, bazując na dwóch zależnościach. Po pierwsze, zakłada się, że 
względna liczba piór zwiększa się wraz ze zmniejszaniem się wielkości ciała ptaków, a po drugie, w przypadku ubarwienia opartego o barwniki karotenoidowe, koncentracja karotenoidów krążących we krwi zmniejsza się wraz ze wzrostem wielkości ciała.

Autorzy analizują związek pomiędzy wielkością ciała (na podstawie masy ciała) i ubarwieniem ptaków korzystając z danych zawartych w pracy Stoddard \& Prum (2011) obejmujących pomiary spektrofotometryczne upierzenia samców 111 gatunków ptaków z 55 rodzin oraz model widzenia ptasiego (Apendyks 1). W analizach autorzy uwzględnili także występowanie dymorfizmu płciowego i środowisko życia ptaka (wyróżniając trzy typy: środowiska otwarte z rzadką, niską roślinnością, środowiska otwarte porośnięte z rzadka drzewami oraz tereny ze zwartym drzewostanem). Pod uwagę wzięto również dane o liczbie piór konturowych, znalezione w literaturze dla 92 gatunków ptaków (Apendyks 2) oraz powiązania filogenetyczne badanych gatunków (Apendyks 3).

W przeciwieństwie do panujących poglądów wykazano, że wraz ze wzrostem masy ptaków rośnie liczba piór konturowych. Stwierdzono negatywną zależność między różnorodnością ubarwienia - określaną jako zakres kolorów w obrębie jednego gatunku (co można uznać jako miarę kontrastu pomiędzy różnymi fragmentami upierzenia tego samego osobnika) a wielkością ciała (kontrolując wpływ powiązań filogenetycznych, dymorfizmu płciowego, sposobu widzenia i habitatu) (Fig. 1). Autorzy sugerują, że przyczyną może być negatywna korelacja pomiędzy koncentracji poziomem karotenoidów we krwi i wielkością ciała ptaków. W związku z wyższym metabolizmem, małe ptaki konsumują relatywnie większe ilości pożywienia, z którego pobierane są karotenoidy, dlatego ilość tych barwników we krwi mniejszych ptaków jest większa. Inna, choć nie wykluczająca się, hipoteza związana jest z komunikacyjną rolą upierzenia i możliwością dostrzeżenia osobnika tego samego gatunku. Małe ptaki, zwykle zamieszkujące bardziej zwarte środowiska, musiały wykształcić bardziej kolorowe ubarwienie w celu ułatwienia relacji międzyosobniczych. Hipoteza ta wiąże się z innym wynikiem pracy — stwierdzono, że różnorodność kolorów jest najniższa u ptaków zamieszkujących tereny otwarte (Fig. 2). 


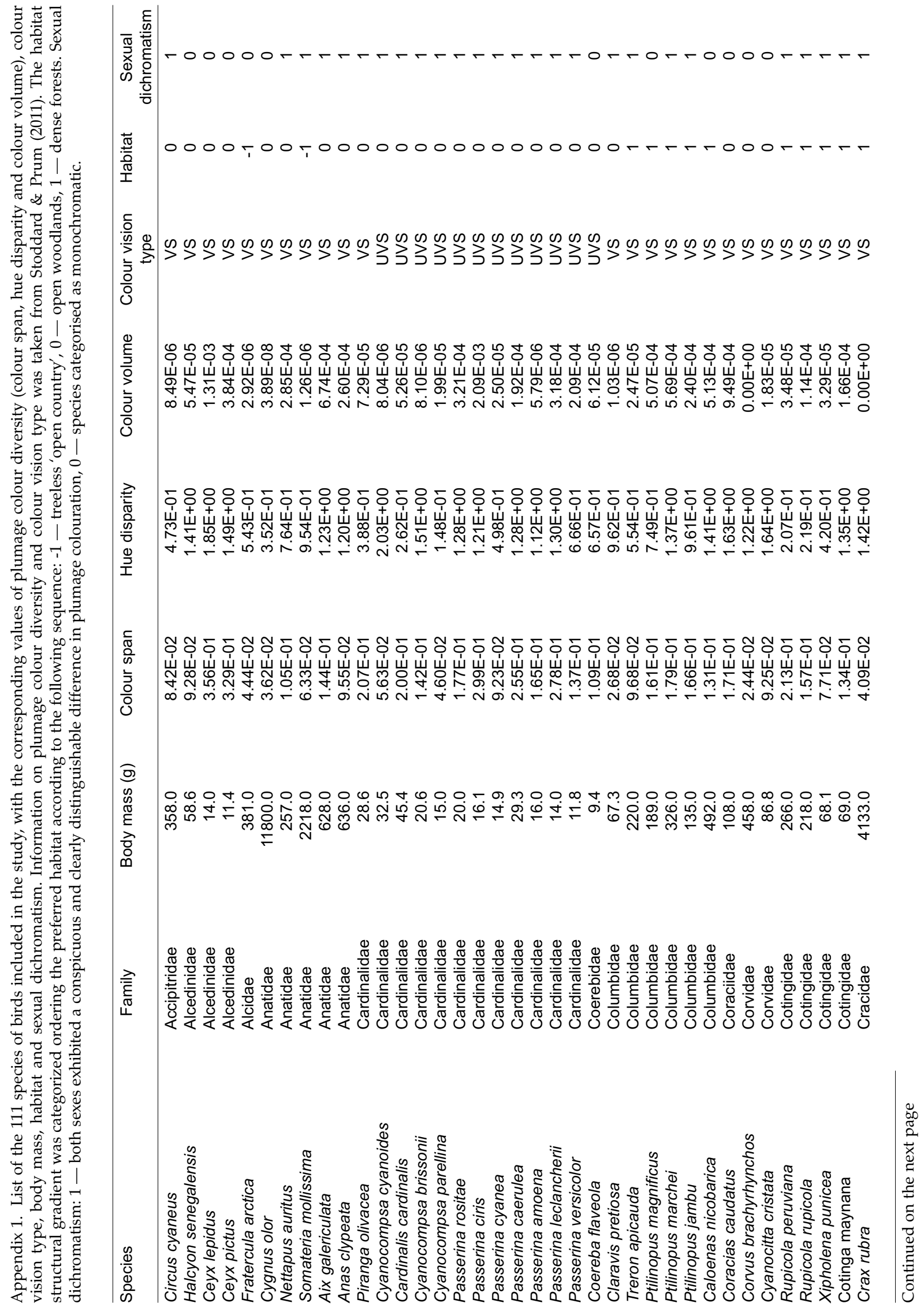




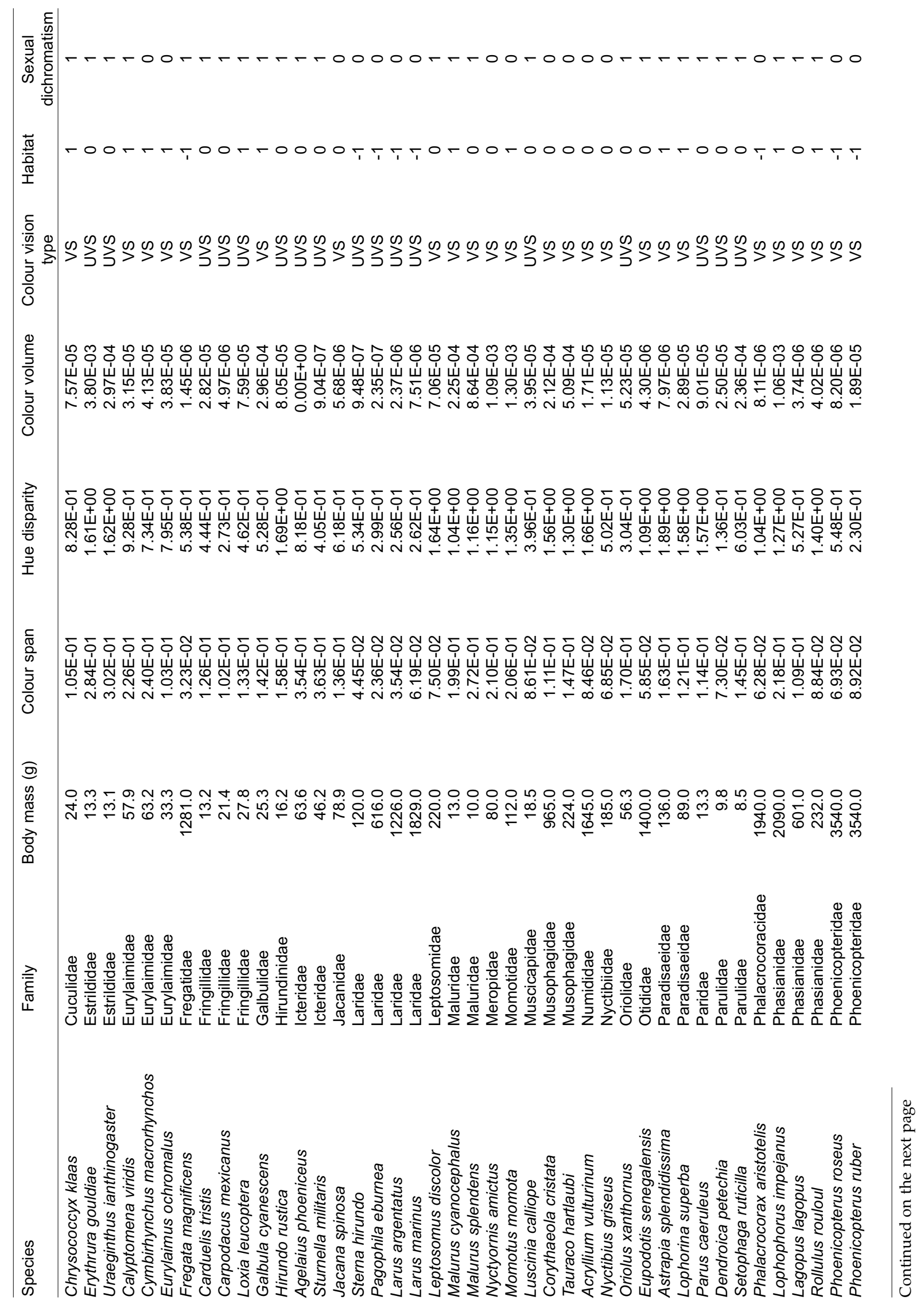




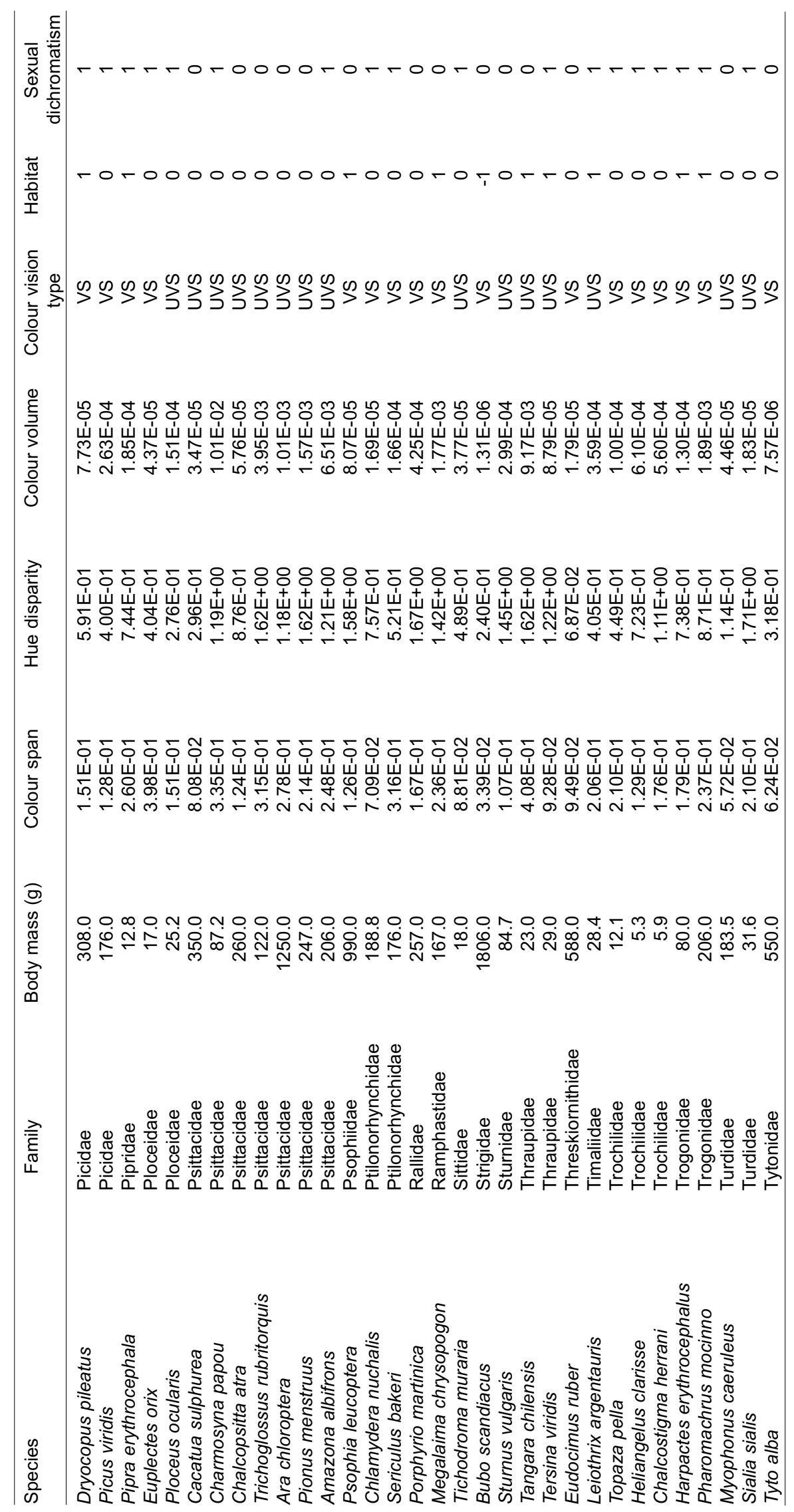


Appendix 2. List of the 92 species of birds with information on number of feathers and body mass. Information on the number of feathers was taken from Wetmore (1936; source 1) and Cambell \& Lack (1985; source 2).

\begin{tabular}{|c|c|c|c|}
\hline Species & No. feathers & Body mass $(\mathrm{g})$ & Source \\
\hline Agelaius phoeniceus & 1639.00 & 42.60 & 1 \\
\hline Ammodramus caudacutus & 1796.00 & 18.50 & 1 \\
\hline Ammodramus henslowii & 1436.00 & 14.60 & 1 \\
\hline Ammodramus maritimus & 1919.00 & 25.40 & 1 \\
\hline Ammodramus savannarum & 1297.33 & 17.73 & 1 \\
\hline Anas crecca & 11450 & 341 & 2 \\
\hline Archilochus colubris & 940 & 3.15 & 2 \\
\hline Archilochus colubris & 940.00 & 2.80 & 1 \\
\hline Calidris minutilla & 4480 & 23.2 & 2 \\
\hline Cardinalis cardinalis & 2280.00 & 44.65 & 1 \\
\hline Carduelis tristis & 1946.20 & 13.30 & 1 \\
\hline Catharus guttatus & 1861.67 & 31.93 & 1 \\
\hline Certhia familiaris & 1327.50 & 8.50 & 1 \\
\hline Chordeiles minor & 2149.50 & 68.60 & 1 \\
\hline Cistothorus palustris & 1433.00 & 11.30 & 1 \\
\hline Contopus virens & 1495.00 & 13.40 & 1 \\
\hline Cyanocitta cristata & 1898.00 & 97.20 & 1 \\
\hline Cygnus columbianus & 25216 & 6650 & 2 \\
\hline Dendroica caerulescens & 1573.50 & 9.45 & 1 \\
\hline Dendroica castanea & 1718.00 & 12.10 & 1 \\
\hline Dendroica coronata & 2143.00 & 12.55 & 1 \\
\hline Dendroica fusca & 1360.00 & 11.20 & 1 \\
\hline Dendroica magnolia & 1514.00 & 8.77 & 1 \\
\hline Dendroica palmarum & 1839.00 & 10.30 & 1 \\
\hline Dendroica pensylvanica & 1411.00 & 11.25 & 1 \\
\hline Dendroica pinus & 1685.00 & 13.90 & 1 \\
\hline Dendroica striata & 1583.00 & 17.60 & 1 \\
\hline Dendroica virens & 1688.00 & 9.20 & 1 \\
\hline Dumetella carolinensis & 1733.00 & 35.60 & 1 \\
\hline Empidonax virescens & 1554.00 & 13.70 & 1 \\
\hline Fulica americana & 13913 & 642 & 2 \\
\hline Geothlypis trichas & 1454.67 & 10.25 & 1 \\
\hline Haliaetus leucocephalus & 7182 & 4740 & 2 \\
\hline Hirundo rustica & 1476.00 & 17.60 & 1 \\
\hline Hylocichla mustelina & 2075.00 & 60.40 & 1 \\
\hline Icteria virens & 2057.00 & 30.20 & 1 \\
\hline Icterus spurius & 1601.00 & 24.00 & 1 \\
\hline Junco hyemalis & 1994.80 & 19.60 & 1 \\
\hline Lanius Iudovicianus & 2170.00 & 50.90 & 1 \\
\hline Melanerpes carolinus & 3665 & 61.7 & 2 \\
\hline Melospiza georgiana & 2085.00 & 17.00 & 1 \\
\hline Melospiza melodia & 2115.57 & 20.90 & 1 \\
\hline Mimus polyglottos & 1601.00 & 51.30 & 1 \\
\hline Mniotilta varia & 1576.00 & 13.70 & 1 \\
\hline Molothrus ater & 1622.00 & 41.40 & 1 \\
\hline Myiarchus crinitus & 1570.00 & 33.80 & 1 \\
\hline Oporornis agilis & 1803.00 & 13.10 & 1 \\
\hline Oporornis formosus & 1511.00 & 14.40 & 1 \\
\hline Parula americana & 1422.00 & 7.70 & 1 \\
\hline Parus carolinensis & 1352.25 & 9.13 & 1 \\
\hline Passer domesticus & 1359.00 & 28.10 & 1 \\
\hline Passerculus sandwichensis & 1747.00 & 17.90 & 1 \\
\hline Passerella iliaca & 2631.25 & 32.30 & 1 \\
\hline Passerina cyanea & 1433.00 & 15.40 & 1 \\
\hline Pheucticus ludovicianus & 2228.00 & 48.20 & 1 \\
\hline Picoides pubescens & 2255.60 & 27.00 & 1 \\
\hline Picoides villosus & 2395.00 & 66.25 & 1 \\
\hline Pipilo erythropthalmus & 2025.50 & 42.00 & 1 \\
\hline
\end{tabular}

Continued on the next page 


\begin{tabular}{|c|c|c|c|}
\hline Species & No. feathers & Body mass (g) & Source \\
\hline Piranga olivacea & 2023.00 & 29.10 & 1 \\
\hline Podilymbus podiceps & 15016 & 442 & 2 \\
\hline Pogoniulus chrysoconus & 2210 & 11.7 & 2 \\
\hline Pooecetes gramineus & 1345.50 & 20.70 & 1 \\
\hline Quiscalus quiscula & 2730.00 & 117.70 & 1 \\
\hline Rallus longirostris & 7224 & 297 & 2 \\
\hline Regulus calendula & 1323.50 & 6.33 & 1 \\
\hline Regulus satrapa & 1295.67 & 5.73 & 1 \\
\hline Sayornis phoebe & 2057.00 & 19.80 & 1 \\
\hline Seiurus aurocapillus & 1849.00 & 21.80 & 1 \\
\hline Seiurus motacilla & 1835.50 & 19.60 & 1 \\
\hline Setophaga ruticilla & 1785.00 & 8.30 & 1 \\
\hline Sialia sialis & 2550.00 & 31.60 & 1 \\
\hline Sphyrapicus varius & 2242.00 & 50.30 & 1 \\
\hline Spizella arborea & 2594.00 & 20.10 & 1 \\
\hline Spizella passerina & 1294.50 & 12.88 & 1 \\
\hline Spizella pusilla & 1693.25 & 11.20 & 1 \\
\hline Stelgidopteryx serripennis & 1369.00 & 17.10 & 1 \\
\hline Streptopelia senegalensis & 4207 & 101 & 2 \\
\hline Strix varia & 9206 & 716.5 & 2 \\
\hline Sturnella magna & 4607 & 89 & 2 \\
\hline Thrythorus ludovicianus & 1405.00 & 21.10 & 1 \\
\hline Toxostoma rufum & 1960.00 & 69.20 & 1 \\
\hline Troglodytes aedon & 1224.50 & 12.40 & 1 \\
\hline Turdus migratorius & 2780.00 & 77.30 & 1 \\
\hline Tyrannus tyrannus & 1868.00 & 40.20 & 1 \\
\hline Vermivora peregrina & 1348.00 & 9.30 & 1 \\
\hline Vireo flavifrons & 1664.00 & 16.60 & 1 \\
\hline Vireo griseus & 1393.25 & 13.48 & 1 \\
\hline Vireo olivaceus & 1608.33 & 17.90 & 1 \\
\hline Wilsonia canadensis & 1435.50 & 9.40 & 1 \\
\hline Zenaida macroura & 2635.00 & 152.70 & 1 \\
\hline Zonotrichia albicollis & 2235.14 & 26.15 & 1 \\
\hline Zosterops pallidus & 3307 & 9.3 & 2 \\
\hline
\end{tabular}


Appendix 3. Phylogenetic hypothesis for the species used in the analyses.

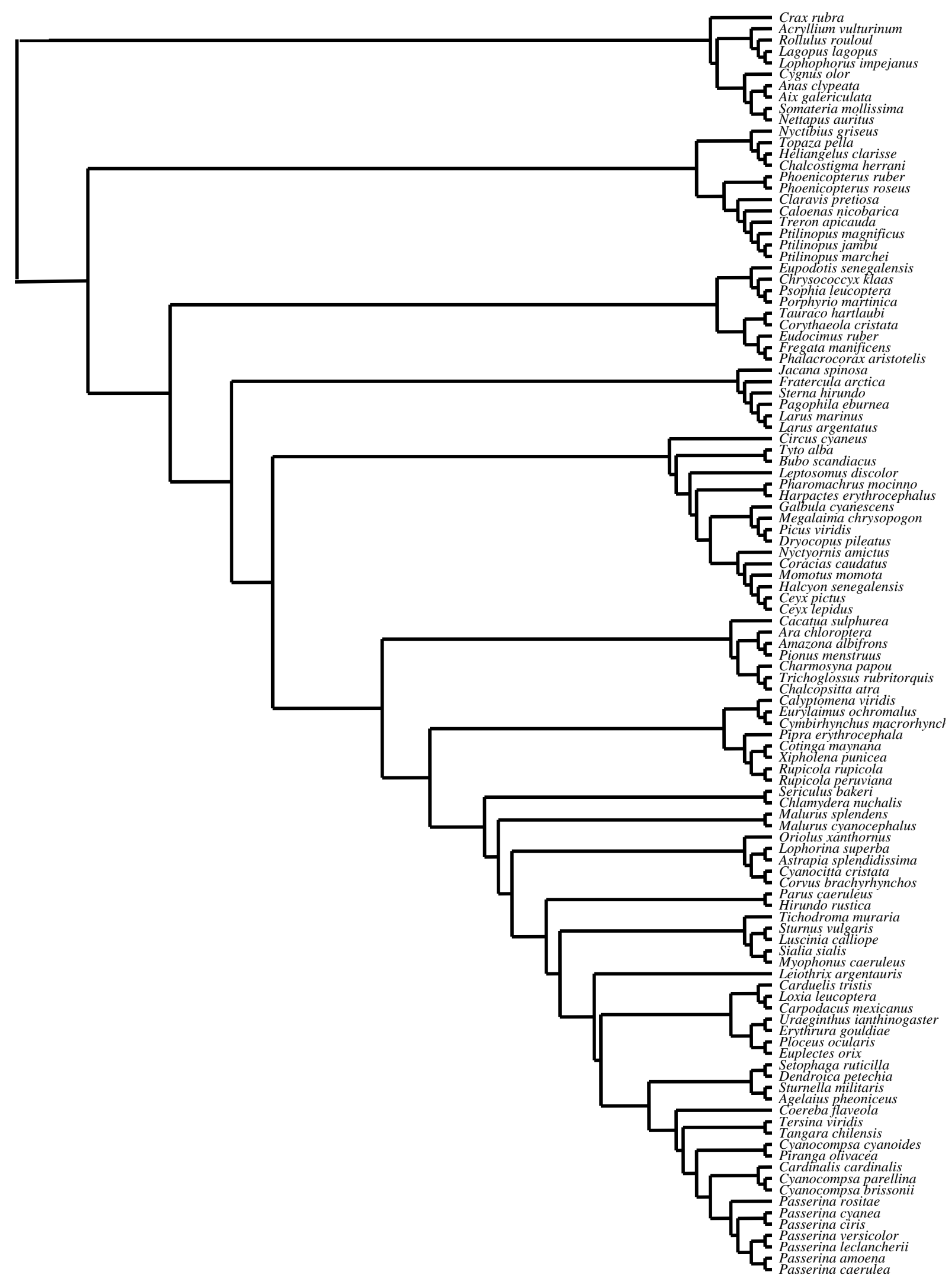

